\title{
EXECUTIVE REMUNERATION IN NEW ZEALAND AND AUSTRALIA: DO CURRENT LAWS, REGULATIONS AND GUIDELINES ENSURE "PAY FOR PERFORMANCE"?
}

\author{
Andreas Schoenemann*
}

\begin{abstract}
This article undertakes an examination of the current corporate governance frameworks relating to the remuneration of executives, and particularly executive directors, of listed companies in New Zealand and Australia. The theoretical background of the article builds on agency theory and managerial power theory. On this basis, performance-related remuneration is identified as crucial in aligning the divergent interests of shareholders and executives. Theories also suggest that the board of directors alone is not a sufficient mechanism to ensure that performance-related pay is implemented in practice. Examination of substantive remuneration rules regarding the structure and form of remuneration agreements finds that in both New Zealand and Australia the relevant problems are only sparsely addressed in enforceable law. More emphasis is put on procedural remuneration rules. Particularly in the fields of disclosure and shareholder involvement, Australia is a step ahead of New Zealand.
\end{abstract}

\section{INTRODUCTION}

Executive remuneration is the subject of lively public and scientific debate. In New Zealand, however, contributions to this debate are relatively infrequent. Executive remuneration levels in New Zealand are low by international standards. Yet this does not indicate that the problems related to remuneration are negligible, as it is not so much the absolute level of remuneration but the composition of remuneration packages that is important. This article aims to enrich New Zealand literature with a contribution focussing on the current state of the New Zealand corporate

* Submitted as part of the LLM programme at Victoria University of Wellington. Joint winner of the 2005 Colin Patterson Memorial Prize. 
governance framework. The article relies on agency theory and the findings made by the advocates of managerial power theory. Remuneration is crucial for aligning interests of shareholders with those of the executive management. For this purpose, remuneration must depend on company performance. Letting the board of directors determine executive remuneration does not, however, ensure this link, as conflicted boards may prefer executives' interests to those of shareholders'. On this theoretical basis, the article examines existing law and regulations that regulate executive remuneration in New Zealand and Australia. It also refers to guidelines without legal force as they have factual influence and can also be precursors to legally enforceable rules. ${ }^{1}$ The point of reference is senior executives and particularly executive directors. The focus is also on publicly listed companies, as agency conflicts appear particularly distinct here. The article addresses problems surrounding the substantive design of remuneration agreements, in particular the link between pay and performance, and points out the fact that hardly any remuneration rule engages in their solution. In contrast to that, the procedural side of executive remuneration is subject to more regulation. This is particularly true for the recently updated Australian regulatory system. In many respects Australia could serve as a role model for New Zealand.

\section{AGENCY CONFLICTS, INCENTIVE PAY AND EXCESS}

\section{A Agency Theory, Managerial Power and Remuneration}

Remuneration of company executives is a classic corporate governance issue. Corporate governance issues arise whenever an agency problem exists that cannot be solved due to incomplete contracts between principal and agent. ${ }^{2}$ An agency relationship exists between shareholders and directors of a company and, as the board delegates control over the day-to-day management to executives, between shareholders and executives as well. ${ }^{3}$ The focus of this article is on the remuneration of senior executives, including directors in their capacity as executives. The agency background for all directors is, however, equally important as the whole board of directors is usually involved in determining executive remuneration. ${ }^{4}$

1 This article will refer to the complete corporate governance framework as "rules", may they be law, selfregulatory means or an "in-between" structure.

2 Oliver Hart "Corporate Governance: Some Theory and Implications" (1995) 105 Economic Journal 678, 678.

3 Company directors and executives are ultimately obliged to represent shareholder interests. In legal terms, however, they are agents of the company which employs them: H A J Ford, R P Austin and I M Ramsay Ford's Principles of Corporations Law (11 ed, Butterworths, Sydney, 2003) 653.

4 The term "management" refers to both directors and executives. If not further specified, the term "director(s)" means both executive and non-executive director(s); the term "executive(s)" refers to both director executives and non-director or sole executives. 
Public companies are particularly characterised by a "separation of ownership and control". 5 The law often provides for only restricted means of shareholder interference with management. ${ }^{6}$ Furthermore, shareholders face collective action problems, particularly in the case of a dispersed shareholder structure. ${ }^{7}$ Small shareholders have free-rider incentives to let others exercise control. ${ }^{8}$ Generally, shareholders may refrain from monitoring their agents due to the costs that are connected with it. ${ }^{9}$ In this situation, the agents do not necessarily pursue shareholder interests. ${ }^{10}$ This constitutes the agency problem. ${ }^{11}$ Instead of maximising shareholder value, ${ }^{12}$ the management may pursue goals beneficial to third parties or themselves. Examples are empire building and suboptimal prestige projects. Deriving financial benefits from one's office for oneself or others is just one aspect of the deviation of interests. ${ }^{13}$

5 Adolf A Berle and Gardiner Means The Modern Corporation and Private Property (Macmillan, New York, 1932) 4.

6 Jaclyn Braunstein "Pound Foolish: Challenging Executive Compensation in the US and the UK" (2004) 29 Brook J Int L 747, 779.

7 Guido Ferrarini and Niamh Moloney Executive Remuneration in the EU: The Context for Reform (ECGI Working Paper, Genoa/Nottingham, 2005) 2.

8 Paul L Davies Introduction to Company Law (Oxford University Press, Oxford, 2002) 140 [Introduction to Company Law]; Hart, above n 2, 680.

9 K A D Camara "Shareholder Voting and the Bundling Problem in Corporate Law" [2004] Wis L Rev 1425, 1473.

10 Berle and Means, above n 5, 4. See also Adam Smith An Inquiry into the Nature and Causes of the Wealth of Nations (5 ed, Methuen, London, 1904) 233.

11 The conflicts in the agency relationship are equally important in the modern law and economics model of the company as a nexus of contracts; for maximising shareholder value is seen as a means of maximising overall firm performance for the benefit of the whole spectrum of the parties affected. Richard Mitchell, Anthony O'Donnell and Ian Ramsay Shareholder Value and Employee Interests: Intersections Between Corporate Governance, Corporate Law and Labour Law (Research Paper, University of Melbourne, 2005) 10.

12 For the purposes of this article, it is assumed that maximisation of shareholder value is the general goal of all shareholders.

13 Lucian Bebchuk and Jesse Fried Pay Without Performance: The Unfulfilled Promise of Executive Compensation (Harvard University Press, Cambridge (Mass), 2004) 16 [Pay Without Performance]; Joseph Healy Corporate Governance and Wealth Creation in New Zealand (Dunmore Press, Palmerston North, 2003) 169; and Michael Jensen and William Meckling "Theory of the Firm: Managerial Behavior, Agency Costs and Ownership Structure" (1976) 3 Journal of Financial Economics 305, 312. 
According to the contractual theory of the corporation, market forces coerce managers to follow shareholder interests. ${ }^{14}$ Generally, the markets for the company's product, corporate control, equity capital and managerial labour provide management with incentives to pursue shareholder interests. ${ }^{15}$ Yet, the practical value of these market constraints is contested by the proponents of the managerialist theory. ${ }^{16}$ While there is no complete market failure, markets still allow considerable deviations from shareholder interests. ${ }^{17}$ The result of insufficient control is managerial power. ${ }^{18}$ There is a wide range of measures suggested to further control management actions. On one side of the spectrum there are enhanced mechanisms of monitoring and control, including strengthened shareholder decision power. On the other side there are incentives granted by the shareholders to their executives. ${ }^{19}$ Providing incentives to act in the shareholders' interests appears preferable to repressive and controlling measures as incentives lead to a voluntary alignment of interests.

Besides some idealistic factors, ${ }^{20}$ monetary compensation is an important part of motivation. ${ }^{21}$ Monetary compensation is further suitable to be used as an incentive mechanism. ${ }^{22}$ For the purposes of setting incentives, fixed salary payments on their own are unhelpful since they cannot sufficiently reflect how efficiently management pursues shareholder interests. ${ }^{23}$ Fixed claims on remuneration

14 R P Austin, H A J Ford and I M Ramsay Company Directors - Principles of Law \& Corporate Governance (LexisNexis Butterworths, Sydney, 2005) 49.

15 See Pay Without Performance, above n 13, for an overview.

16 Michael B Dorff "Does One Hand Wash the Other? Testing the Managerial Power and Optimal Contracting Theories of Executive Compensation" (2005) 30 J Corp L 255, 258 ["Does One Hand Wash the Other"].

17 Compare Pay Without Performance, above n 13, 58.

18 For example, the concept of managerial power is recognised in John E Core, Wayne R Guay, and Randall S Thomas Is U.S. CEO Compensation Inefficient Pay Without Performance? (Law \& Economics Working Paper Series - Working Paper No 05-05, Vanderbilt University Law School, 2004). Yet in contrast to many others, the authors do not draw any negative conclusions for the context of remuneration.

19 In the remuneration debate, the term incentive is used with various meanings, sometimes as a single element of a remuneration package. For the purposes of this article, the term is used more generally for every positive motivational factor.

20 Healy, above n 13, 187.

21 For criticism of the overemphasis put on idealistic motivations, see Graef S Crystal Executive Compensation - Money, Motivation, and Imagination (2 ed, Amacom, New York, 1978) 3.

22 Compare Paul L Davies "Disclosure, Audit and Executive Remuneration: A Eurocentric View" (2004 Parsons Address, Sydney, 2004) 5. Monetary compensation in this sense may consist of cash payments and may further, but not exclusively, include shares, share options, retirement benefits, benefits in kind or a mixture of all of them.

23 Pay Without Performance, above n 13, 122; Stephen M Bainbridge "Executive Compensation: Who Decides?" (2005) 83 Tex L Rev 1615, 1621 ["Who Decides"]. 
are assumed to cause conflicting interests to diverge even further, ${ }^{24}$ as executives become riskaverse $^{25}$ and prefer the preservation of assets over creating new wealth. ${ }^{26}$ The 1995 Greenbury Report on directors' remuneration rightly emphasised performance-linked rewards as the key to enhancing directors' and executives' performance and to aligning their interests with those of shareholders. ${ }^{27}$ This view is widely shared today. ${ }^{28}$

\section{B Excessive Remuneration}

Remuneration arrangements can be judged on the basis of either the absolute amounts or the structure and form of rewards. ${ }^{29}$ It is the structure and form of the awards which are of pre-eminent importance. ${ }^{30}$ Even excessively large payments may be appropriate in the sense that promising them provides an effective incentive to increase shareholder wealth. ${ }^{31}$ Or conversely, "for a given level of pay, if incentives are too low, then pay is too high." ${ }^{32}$ Excess in this sense is what is paid without providing effective incentives and thus constitutes a shift of wealth from shareholders to executives without return.

A populist point of view focuses on inflated absolute amounts which are compared to average incomes. ${ }^{33}$ This view is advocated particularly by the media and worker representatives. ${ }^{34}$

24 "Who Decides", above n 23, 1621.

25 Camara, above n 9, 1443.

26 Michael Jensen A Theory of the Firm: Governance, Residual Claims, and Organizational Forms (Harvard University Press, Cambridge (Mass), 2000) 145; "Who Decides", above n 23, 1621.

27 Greenbury Committee Directors' Remuneration: Report of a Study Group Chaired by Sir Richard Greenbury (Gee Publishing, London, 1995) para 1.15 [Greenbury Report].

28 Crystal, above n 21, 9. See also Jennifer Hill "'What Reward Have Ye?' Disclosure of Director and Executive Remuneration in Australia" (1996) 14 Comp \& Sec LJ 232, 235 ["What Reward Have Ye?"]. For criticisms of remuneration incentives see Camara, above n 9, 1443.

29 Compare the trichotomy of amounts, structure and form examined by Ruth Bender and Brenda Porter $A$ System for Setting Executive Directors' Remuneration (Research Paper, Cranfield School of Management, 2001) 4. The second and third group are closely related.

30 Michael C Jensen and Kevin J Murphy "CEO Incentives - It's Not How Much You Pay, But How" [1990] Harvard Business Review 138, 144 ["CEO Incentives"].

31 Healy, above n 13, 170; Pay Without Performance, above n 13, 8 and 123.

32 Core, above n $18,41$.

33 Pay Without Performance, above n 13, 8.

34 See for example John Shields, Michael O'Donnell and John O'Brien The Bucks Stop Here: Private Sector Executive Remuneration in Australia (Labour Council of NSW Report, Sydney, 2003) $<$ http://www.council.labour.net.au> (last accessed 16 April 2006). 
Interestingly, the New Zealand Shareholders' Association (NZSA) also stresses this aspect of the debate. ${ }^{35}$ This is not the place to discuss the merits of a distributive fairness approach. However, on the basis of the primacy of shareholder value, differences in absolute pay quantities must not entirely be neglected. Research has found that large pay disparities impact negatively on productivity as they lower worker morale and, particularly in middle-management, lead to a higher turnover. ${ }^{36}$ This psychological side-effect of remuneration on shareholder value must be considered and may operate to set limits on absolute amounts.

\section{PROBLEMS WITH IMPLEMENTING INCENTIVE PAY}

\section{A Board Competence for Remuneration Decisions}

In order to relate pay to performance the process of determining remuneration is crucial. In both New Zealand and Australia, the board of directors is responsible for implementing remuneration policy and individual agreements. Under the New Zealand Companies Act 1993, the remuneration of directors is a board competence. ${ }^{37}$ While sole directors are not the focus of this article, the relevant provision encompasses the remuneration of directors in any capacity, thus also as executive employees. ${ }^{38}$ For listed companies this is no different. While directors' remuneration is, in accordance with the New Zealand Stock Exchange (NZX) Listing Rules, subject to an ordinary shareholder resolution, ${ }^{39}$ remuneration paid to directors for services in the capacity of executive is not subject to that rule. ${ }^{40}$ The remuneration of sole senior executives is not specifically regulated but is a fortiori a matter for the board to decide. ${ }^{41}$

35 Bruce Sheppard NZSA - Chief Executive Pay (Discussion Document, Auckland, 16 June 2004) $<$ http://www.nzshareholders.co.nz> (last accessed 16 April 2006) section 12.

36 Randall S Thomas "Should Directors Reduce Executive Pay?" (2003) 54 Hastings L J 437, 438. See also Charles M Yablon "Overcompensating: The Corporate Lawyer and Executive Pay" (1992) 92 Colum L Rev 1867, 1877. Crystal, above n 21, 18, stresses that a legitimate goal of remuneration schemes is to increase turnover among "low quality personnel".

37 Companies Act 1993, s 161(1).

38 Companies Act 1993, s 161(1)(a). See also Victoria Law (ed) Brookers - Company and Securities Law (loose leaf, Brookers, Wellington, Companies Act, 2003) para CA161.01 (last updated 23 September 2004) [Brookers - Company and Securities Law].

39 New Zealand Stock Exchange Listing Rules (1 May 2004) r 3.5.1 [NZX Listing Rules]. Note that section 161(1) of the Companies Act 1993 allows this "restoration" of shareholder competence by means of a provision in the company's constitution.

40 NZX Listing Rules, above n 39, r 3.5.1.

41 Remuneration of sole senior executives may not even be a competence of, for example, the chief executive officer. 
For Australian public companies, related party transaction provisions require shareholder approval of the remuneration of directors. ${ }^{42}$ However, remuneration for directors acting as executives is excluded from the scope of the relevant provisions as long as it is "reasonable". 43 Therefore, there is no automatic requirement for shareholder decisions. Like the NZX Listing Rules, the Australian Stock Exchange (ASX) Listing Rules do not require shareholder approval. ${ }^{44}$

\section{B The Conflict of Interest in Setting Remuneration}

Despite the obvious situation of self-interest, New Zealand law allows executive directors to be among those who determine their own remuneration. ${ }^{45}$ Only "[c]ommon sense and prudent practice suggest ... that the director who is to receive the remuneration etc should not vote on such a resolution." ${ }^{46}$ In Australian public companies the conflict of interest is not that obvious as directly self-interested directors cannot be present or vote on their own remuneration. ${ }^{47}$ Yet, there is a wider sort of conflict of interest. The following arguments are relevant for non-director senior executives as well. At its roots, the conflict is no other than the principal-agent conflict described above. ${ }^{48}$ Market forces insufficiently align directors' actions with shareholder interests; thus directors do not necessarily strive for implementing performance-related pay. ${ }^{49}$ Instead, there is a spectrum of motivations to favour the pecuniary interests of fellow executive board members or executives in general. ${ }^{50}$

First, there is the directors' economic interest in their positions, which promise pecuniary and also reputational benefits. ${ }^{51}$ Particularly, the chief executive may have influence over the

42 Corporations Act 2001 (Cth), s 228(2) treats directors as related parties under the related party transaction provisions of Part E and thus requires shareholder approval under section 208.

43 Corporations Act 2001 (Cth), s 211.

44 Australian Stock Exchange Listing Rules (10 June 2005), r 10.17 [ASX Listing Rules].

45 While section 161 of the Companies Act 1993 requires "fairness" of the remuneration and entry into the interest register it does not preclude the director concerned from voting; see Brookers - Company and Securities Law, above n 38, para CA161.02.

46 Brookers - Company and Securities Law, above n 38, para CA161.02.

47 Corporations Act 2001 (Cth), s 195.

48 See Part II A Agency Theory, Managerial Power and Remuneration.

49 Pay Without Performance, above n 13, 23.

50 See, for a practical approach, the experimental model described by Dorff, "Does One Hand Wash the Other", above n 16.

51 Michael B Dorff "Softening Pharaoh's Heart: Harnessing Altruistic Theory and Behavioral Law and Economics to Rein in Executive Salaries" (2003) 51 Buff L Rev 811, 848 ["Altruistic Theory"]. 
appointment of the members of the deciding board. ${ }^{52}$ Directors may feel gratitude for help they received in being appointed. Once appointed, they may fear a negative influence on their further careers. ${ }^{53}$ Beyond that, "mutual back scratching" between board members sitting on the same board or holding cross-directorships is a concern. ${ }^{54}$ Directors striving for executive positions themselves may also be inclined to favour executive-friendly remuneration policies. ${ }^{55}$ Furthermore, there is a range of social and psychological factors. Potential influence starts with close personal relationships such as friendships. ${ }^{56}$ But even team spirit or simple apathy might cause a board to avoid direct conflict over remuneration issues. ${ }^{57}$ At the same time, the downsides of making executive-friendly remuneration decisions are relatively low. This is particularly true if gifts to executives are sufficiently camouflaged - a practice for which there is evidence in the United States. ${ }^{58}$ The board competence for determining pay arrangements for executive directors or sole executives is thus burdened with conflicts of interest. The traditional board structure does not counter this conflict. Measures already taken and possible future measures are discussed below. ${ }^{59}$

\section{CORPORATE GOVERNANCE FRAMEWORKS IN NEW ZEALAND AND AUSTRALIA}

It is helpful to briefly present the cornerstones of the corporate governance frameworks for executive remuneration. Corporate governance is determined by various regulatory means. "Hard law" constitutes the inner core of the corporate governance framework. ${ }^{60}$ It is followed by "semihard" law (such as listing rules and accounting standards) which is usually privately established but recognised by statute, supervised by the State and to some extent enforceable. ${ }^{61}$ It is often designed

52 "Altruistic Theory", above n 51, 844. Nomination committees may be able to reduce that influence but not eliminate it entirely.

53 Edward M Iacobucci "The Effects of Disclosure on Executive Compensation" (1998) 48 U Toronto LJ 489 , 496; Ferrarini and Moloney, above n 7, 9.

54 Greenbury Report, above n 27, para 4.8.

55 Introduction to Company Law, above n 8, 206.

56 Pay Without Performance, above n 13, 31.

57 Ferrarini and Moloney, above n 7, 9; "Altruistic Theory", above n 51, 854.

58 Iman Anabtawi "Secret Compensation" (2004) 82 N C L Rev 835, 838; Lucian Bebchuk and Jesse Fried "Stealth Compensation via Retirement Benefits" (2004) 1 Berkeley Bus LJ 291 ["Stealth Compensation"].

59 See Part VI Procedural Issues.

60 John H Farrar Corporate Governance - Theories, Principles, and Practice (2 ed, Oxford University Press, Melbourne, 2004) 348.

61 Farrar, above n 60, 351 and 353. 
as a "comply or explain" regime to preserve business flexibility. ${ }^{62}$ Beyond that, there are codes and guidelines with the character of recommendations only. They are self-regulatory "soft law". ${ }^{63}$ Soft law reflects standards accepted by the relevant circles. It is the basis for pressure exerted by shareholder representatives or institutional investors and, moreover, a possible precursor to legally enforceable rules.

In New Zealand, the inner core of binding rules is the Companies Act 1993; it contains provisions as to the fairness of remuneration ${ }^{64}$ and certain disclosure requirements. ${ }^{65}$ For listed companies, the semi-hard NZX Listing Rules are applicable. They contain the above-mentioned requirements regarding the setting of directors' remuneration. The NZX Best Practice Code contains further "comply or disclose" provisions. ${ }^{66}$ Like the Listing Rules, the NZX Best Practice Code only addresses directors' remuneration. This obviously leaves out non-director executives; but in view of the non-applicability of the Listing Rules to the executive remuneration of directors, the applicability of the Best Practice Code in this respect is doubtful ${ }^{67}$ It would be helpful to clearly acknowledge the different categories of directors, executive directors and non-director executives and to recognise the need for differing demands on remuneration. ${ }^{68}$ The soft recommendations issued by the Securities Commission are of subsidiary importance. ${ }^{69}$

The Australian Corporations Act 2001 contains various detailed provisions as to the setting of remuneration, its reasonableness, some distinct components, and disclosure regulations. ${ }^{70}$ The Australian Accounting Standards Board (AASB) Standards provide additional provisions. ${ }^{71}$ For

62 Still, such a regime can impose strong constraints. James McConvill and John Bingham provocatively speak of a "comply or comply" regime in "Comply or Comply: The Illusion of Voluntary Corporate Governance in Australia" (2004) 22 Comp \& Sec LJ 208 ["Comply or Comply"].

63 For self-regulation see Farrar, above n 60, 249.

64 Companies Act 1993, s 161.

65 Companies Act 1993, s 211.

66 NZX Listing Rules, above n 39, Appendix 16 "Corporate Governance Best Practice Code" [NZX Best Practice Code]. Note that no explanation is required, NZX Listing Rules, above n 39, r 10.5.3(i).

67 See Part VI B 1 Remuneration committees.

68 This would be in line with the Securities Commission's Guidelines, Securities Commission of New Zealand Corporate Governance in New Zealand - Principles and Guidelines (2004) <http://www.sec-com.govt.nz> (last accessed 16 April 2006) [SCNZ Guidelines].

69 SCNZ Guidelines, above n 68.

70 They have last been updated in the context of the Corporate Law Economic Reform Program (CLERP) 9 reform in mid-2004.

71 Australian Accounting Standards Board (31 December 2005) Standard 124. This is the successor of Standard 1046 in this context. 
listed companies the ASX Listing Rules ${ }^{72}$ and particularly Principle 9 of the ASX Corporate Governance Council Principles of Good Corporate Governance and Best Practice Recommendations (ASX Principles) are of importance. ${ }^{73}$ The ASX Principles work on a "comply or explain" basis. ${ }^{74}$ It should be noted that the ASX Listing Rules also apply to New Zealand companies that are listed on the $\mathrm{ASX} .^{75}$ As their requirements for executive remuneration are considerably higher, they factually supersede the NZX Listing Rules. On the soft law part, this article considers the Investment \& Financial Services Association (IFSA) Guidance Notes $^{76}$ and the recently updated Corporate Governance Guidelines issued by the Australian Council of Superannuation Investors (ACSI). ${ }^{77}$

\section{SUBSTANTIVE ISSUES OF REMUNERATION AGREEMENTS}

\section{A Regulation of Remuneration Agreements}

The discussion of remuneration theory has identified two key points. First, remuneration should have a strong incentive effect and thus be performance-related. Second, due to potential conflicts of interest, safeguarding the objectivity of the remunerating process is crucial. This section considers the issues connected with the first key point. In order to facilitate the reference to one or the other group of issues, the first is referred to as substantive and the second as procedural issues. ${ }^{78}$ Prescribing the content of remuneration agreements is in itself a procedural matter and so certain overlaps appear. ${ }^{79}$

72 ASX Listing Rules, above n 44.

73 ASX Corporate Governance Council Principles of Good Corporate Governance and Best Practice Recommendations (1 March 2003) <http://www.asx.com.au> (last accessed 16 April 2006) [ASX Principles].

74 ASX Listing Rules, above n 44, r 4.10.

75 The ASX Listing Rules are applicable to all companies listed on the ASX: ASX Listing Rules, above n 44, r 1.16 and 18.6.

76 Investment \& Financial Services Association Guidance Note No 12 - Executive Share and Option Scheme Guidelines (2000) <http://www.ifsa.com.au> (last accessed 16 April 2006) [IFSA Guidance Note No 12], which is also endorsed by various other organisations.

77 Australian Council of Superannuation Investors Corporate Governance Guidelines for Superannuation Fund Trustees and Corporations (2005) <http://www.acsi.org.au $>$ (last accessed 16 April 2006) [ACSI Guidelines]. In New Zealand, no private code is considered as such. Yet the views of the NZSA are referred to as literature.

78 This somewhat legalistic terminology is not meant to imply that one group or another is attributed primary importance per se.

79 The discussion of substantive issues is nevertheless seen as a discussion in its own right. 
Substantive remuneration is the domain of soft-law recommendations and voluntary selfregulation. Hard or semi-hard law provisions are rare. Currently, the only general provisions of an at least partly substantive nature contained in both the Australian Corporations Act 2001 and the New Zealand Companies Act 1993 are what can be called fairness provisions. ${ }^{80}$ In New Zealand, the board of directors may authorise the payment of remuneration to directors if this is "fair to the company." 81 Much of this provision is unclear. Remuneration is understood to be relatively broad but is not defined. ${ }^{82}$ More importantly, there is neither a statutory definition nor any conclusive judicial comment on the meaning of the term "fair". ${ }^{83}$ Commentary indicates that fairness relates to the quantity of remuneration rather than the make-up of remuneration agreements. ${ }^{84}$ As stated above, any dollar spent on remuneration without providing further incentives is spent in excess. However, regarding greater amounts of non-performance-related salaries as unfair to the company does not correspond with the purpose of the Companies Act $1993 .{ }^{85}$ Thus, the fairness provision is not very helpful in providing practical guidance as to the make-up of remuneration agreements. ${ }^{86}$ Much the same is true for the Australian Corporations Act 2001. As stated above, the Corporations Act 2001 exempts public companies from member approval if the remuneration is reasonable, adding that both the situation of the company and the individual must be considered. ${ }^{87}$ Guidance as to the make-up of the remuneration is absent. ${ }^{88}$ The focus, again, is on quantity.

The make-up and components of remuneration packages are discussed next. Thereby, a clear distinction is made between components that are related to performance and those that are not. In

80 Companies Act 1993, s 161(1) and Corporations Act 2001 (Cth), s 211(1)(b). In a wider sense one could also count the general directors' duties to act in the best interests of the company (Corporations Act 2001 (Cth), Chapter 2D) or oppression provisions as in section 234 of the Corporations Act 2001 (Cth). See Anne Ward and Chris Burubu Executive Remuneration: Where are We and Where are We Headed (MinterEllison Articles, Australia, 19 September 2003) <http://www.minterellison.com> (last accessed 16 April 2006).

81 Companies Act 1993, s 161(1).

82 Common benefits such as insurance, share options, salaries, and motor vehicles are presumably covered Brookers - Company and Securities Law, above n 38, para CA161.02.

83 Brookers - Company and Securities Law, above n 38, para CA161.02.

84 Brookers - Company and Securities Law, above n 38, para CA161.02.

85 Note that the Companies Act was enacted in 1993 and thus before the remuneration debate gained worldwide importance. The Greenbury Report in the UK was only published in 1995.

86 A different question is whether external corporate governance standards can satisfy the term "fair". For this discussion see Part VI A Government Intervention.

87 Corporations Act 2001 (Cth), s 211(1)(b).

88 Even the guidelines in section $243 \mathrm{~N}$ of the former Corporations Law are no longer part of the Corporations Act 2001 (Cth). Some guidance is given by ASIC v Adler [2002] NSWSC 171. 
recognition of the high relevance attributed to them in the current debates, separate attention is dedicated to termination payments. ${ }^{89}$

\section{B Fixed Remuneration}

In Australia, the ASX Principles suggest fixed remuneration components ${ }^{90}$ and so do - on the soft-law part - the ACSI Guidelines. ${ }^{91}$ In New Zealand, the NZX Best Practice Code seems to concentrate on fixed remuneration as the basic premise and encourages directors ${ }^{92}$ to only link part of their remuneration to performance. ${ }^{93}$ This wording reflects the relatively low use of performancerelated pay in New Zealand. ${ }^{94}$ Fixed salary components, however, lack the incentives aligning the interests of shareholders and executives. ${ }^{95}$ So why not pay on a performance-only base? While shareholders can reduce their personal risk by spreading their investment, executives are, as far as their employment is concerned, undiversified and therefore considerably tied to the welfare of their employer company. ${ }^{96}$ The more performance components a remuneration package contains, the higher is the executive's risk. Therefore executives strive at least for a certain amount of fixed base

89 See for example Australian Council of Superannuation Investors "Time for an Informed Debate on Termination Payments for Executives" (17 March 2005) Press Release, and the English discussion in Department of Trade and Industry "Rewards for Failure": Directors' Remuneration - Contracts, Performance and Severance (Consultative Document, London, June 2003) para 3.8 [DTI Rewards for Failure].

90 Benefits in kind are regularly part of the fixed payments. They cannot be addressed separately due to the scope of this article. ASX Principles, above n 73, Principle 9.2 (Box 9.2).

91 ACSI Guidelines, above n 77, para 14.3.

92 Apparently both executive and non-executive; thus this is a rather general statement.

93 Compare for example the NZX Best Practice Code, above n 66, para 2.7; SCNZ Guidelines, above n 68, Principle 5.4.

94 According to Sheffield CEO Survey 2005 (Sheffield, Auckland, 2005) 78, only 73 per cent of CEOs of New Zealand listed companies declared they had some sort of performance-related component in their remuneration package. Performance pay constituted 31 per cent of total remuneration costs. These numbers have to be treated with some caution as the sample size is relatively low. However, the numbers are consistent with the data cited by Healy, above n 13, 174 for 2000 .

95 "Who Decides", above n 23, 1621. Not surprisingly, a study conducted for Australia on the basis of base salaries could not identify a link between pay and performance: P Holland, P J Dowling and P A Innes Principles, Policies and Practices of CEO Compensation in Australia: Is there a Relationship? (Working Paper, Launceton School of Management, 2000).

96 See Kevin J Murphy "Explaining Executive Compensation: Managerial Power versus the Perceived Cost of Stock Options" (2002) 69 U Chi L Rev 847, 858 ["Explaining Executive Compensation"]; Pay Without Performance, above n 13, 18 . 
pay to avoid major downward variations of their income. ${ }^{97}$ Conversely, from a company point of view, providing this fixed minimum can positively influence the value attributed by the executives to the remaining at-risk components. ${ }^{98}$ According to Murphy, employees demand large risk premiums when paid in options, lowering the individual option value below the standardised value attributed to them if traded freely on an exchange. ${ }^{99}$ This effect can be reduced if a certain level of base salary is secured.

The question remains how base salary components should be structured. The ASX Principles somewhat nebulously suggest that fixed remuneration components should reflect the core performance requirements and expectations. ${ }^{100}$ While being in itself static, fixed salary can still reflect performance expectations. It is unreasonable to award performance premiums before a performance target is reached. Base salary can, however, reflect highly ambitious performance targets. The less likely it is that targets can be reached, the higher the risk premium will be. On this premise, base salary should reflect the individual situation of the executive - meaning, above all, the personal financial standing of the executive and their willingness or ability to take risks. ${ }^{101}$ This point is widely disregarded by remuneration rules. ${ }^{102}$ Instead, legal, industrial and other obligations of the company and especially the scale of the business - measured by sales, assets, number of employees or total market capitalisation - get all the attention. ${ }^{103}$ In New Zealand, where performance-related components are underrepresented, the use of such guidance may partly explain why studies find that remuneration is linked to company size. ${ }^{104}$ Fostering such a link is

97 Healy, above $\mathrm{n} \mathrm{13,171.} \mathrm{See} \mathrm{also} \mathrm{the} \mathrm{analysis} \mathrm{concerning} \mathrm{the} \mathrm{risk} \mathrm{aversion} \mathrm{of} \mathrm{executives} \mathrm{by} \mathrm{Hamid} \mathrm{Mehran}$ "Executive Incentive Plans, Corporate Control, and Capital Structure" (1992) 27 JFQA 539, 543; Matthew $\mathrm{C}$ Bloom and George T Milkovich The Relationship between Risk, Incentive Pay, and Organizational Performance (Center for Advanced Human Resource Studies (CAHRS) Working Paper Series - No 97-23, Cornell University, 1997) 7.

98 Core, above n $18,41$.

99 "Explaining Executive Compensation", above n 96, 858. See also Michael C Jensen, Kevin J Murphy and Eric G Wruck Remuneration: Where We've Been, How We Got to Here, What are the Problems, and How to Fix them (ECGI Working Paper, Cambridge (Mass), July 2004) 65 [Remuneration: Where We've Been].

100 ASX Principles, above n 73, Principle 9.2.

101 For example, a financially well-established CEO can be expected to be willing to take a greater portion of his or her remuneration at risk.

102 Note that the "reasonableness" in section 211 of the Corporations Act 2001 (Cth) includes a "personal" element (Corporations Act 2001 (Cth), s 211(1)(b)(ii)). Yet Ford, above n 3, 454, rejects that it refers to the personal situation of the officer concerned.

103 ASX Principles, above n 73, Principle 9.2; ACSI Guidelines, above n 77, para 14.3.

104 Healy, above n 13, 173; Aleksandar Andjelkovic, Glenn Boyle and Warren McNoe "Public Disclosure of Executive Compensation: Do Shareholders Need to Know?" (2002) 10 Pacific Basin Finance Journal 97, 99. 
questionable as it encourages executives to engage in potentially counterproductive empire building. ${ }^{105}$

\section{Performance Components}

The emphasis must lie on the performance components of executive remuneration. While virtually all remuneration rules issued during the last few years embrace the concept of performance-related remuneration components, they show differences in their details. The main distinction between the suggested instruments relates to the time horizon of the performance targets. Short-term incentive plans (STIPs) appear to be the most common incentive granted to chief executives in New Zealand and Australia. ${ }^{106}$ The typical time horizon is the one-year accounting period. STIPs are usually implemented as cash bonuses. ${ }^{107}$ Long-term incentive plans (LTIPs) are usually on an equity base as a share-ownership or share-option scheme. ${ }^{108}$ Surprisingly few listed New Zealand companies appear to make use of such a LTIP for their chief executives. ${ }^{109}$ Remuneration regulations and guidelines make few statements as to a preference for either type of component. Only the ACSI Guidelines stress the importance of long-term performance. Express statements of preference for LTIPs should be considered - particularly with regard to the clear focus on short-term incentives in New Zealand. The model shareholder of corporate governance regulations and guidelines is the business owner who is interested in long-term business value through sustainable growth. ${ }^{110}$ Institutional shareholders are also attributed an important role. ${ }^{111}$

105 Healy, above n 13, 173.

106 According to Australian Council of Superannuation Investors CEO Pay in the Top 100 Companies: 2003 (2004) < http://www.acsi.org.au> (last accessed 16 April 2006) para 4.1.2 [ACSI CEO Pay] roughly 80 per cent of the top 100 listed Australian companies had a STIP in place for their chief executive in 2003. In New Zealand, the Sheffield CEO Survey 2005, above n 94, 78, states that of all listed companies 63 per cent of all chief executives received payments under a STIP.

107 On very few occasions deferred shares are granted. Compare for example ACSI CEO Pay, above n 106, para 4.1.2.

108 Note that some authors use LTIP as a general term, as it is done here, while others restrict it to particular design forms. See for example Alistair Bruce and Trevor Buck "Executive Pay and UK Corporate Governance" in K Keasy (ed) Corporate Governance: Accountability, Enterprise and International Comparisons (Wiley \& Sons, Hoboken (NJ, USA), 2005) 117, 127.

109 Healy, above n 13, 174, states that no remuneration was paid under LTIPs in 2000. More recent data provided by Sheffield CEO Survey 2005, above n 94, 78, shows that still only 12 per cent of the survey sample of listed company chief executives take part in a share ownership scheme of any sort. Again, this value is based on a relatively small sample and must be treated with caution.

110 Charlotte Villiers "Share Option Plans for Directors in Privatised Companies in the United Kingdom and Spain" (2001) 22 Comp Law 139, 142. See also Sheppard, above n 35, para 3. 
While they pursue their specific investment and divestment strategies, which may interrupt the longterm perspective at times, ${ }^{112}$ they generally follow long-term oriented strategies. ${ }^{113}$

\section{STIPs and bonus schemes}

Bonus schemes as such are generally not addressed in remuneration regulations and guidelines. Therefore, it must be feared that problematic issues around STIP bonus schemes largely elude scrutiny by boards and shareholders. In view of this, at least the ACSI has recently included further provisions in its Guidelines. ${ }^{114}$ Healy notes the poor structure of bonus components of remuneration packages in New Zealand. ${ }^{115}$ Under bonus schemes a certain base level of remuneration often develops which is paid out irrespective of minimum performance standards being met. ${ }^{116}$ The bonus becomes partly a fixed component disguised as performance-related remuneration. At the other end, bonus payments are capped at a certain point, due to the design of the scheme or the factual development over time, ${ }^{117}$ taking away the incentive effect from the cap onwards.

A point worthy of consideration is the type of performance target underlying a bonus scheme. Targets reflecting the individual performance, as suggested by the New Zealand Securities Commission, ${ }^{118}$ should be viewed with caution. Examples of these targets include effective leadership or making important strategic decisions. They involve inherently subjective evaluation and discretion. ${ }^{119}$ Discretion, in turn, opens the gate to the very problems arising in the managerial

111 Marianne Bertrand and Sendhil Mullainathan "Agents With and Without Principals" (2000) 90 AER 203, 206 ["Agents With and Without Principals"]; Mohammed B Hemraj "How Shareholders' Activism can Refrain Directors from Highjacking the Company" (2003) 24 Comp Law 345, 346.

112 Sheppard, above n 35, para 3. See also Ferrarini and Moloney, above n 7, 10; Albie Brooks, Keryn Chalmers, Judy Oliver and Angelo Veljanovski "Issues Associated with Chief Executive Officer Remuneration: Shareholders' Perspectives" (1999) 17 Comp \& Sec LJ 360, 361

113 ACSI Guidelines, above n 77, para 14.

114 Australian Council of Superannuation Investors The Incentive Components of Executive Pay (2004) $<$ http://www.acsi.org.au $>$ (last accessed 16 April 2006) para 4.1 [ACSI Incentive Components]; ACSI Guidelines, above n 77, para 14.4.

115 Healy, above n 13, 175.

116 Healy, above n 13, 175; Crystal, above n 21, 110. See also McBride HR "Bonuses Paid for NonPerformance" (11 August 2004) Press Release.

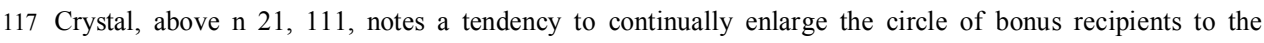
detriment of the original eligibles.

118 SCNZ Guidelines, above n 68, Principle 5.4.

119 Pay Without Performance, above n 13, 126; Paul Oyer and Kevin J Murphy Discretion in Executive Incentive Contracts (Working Paper, Marshall School of Business USC, 2003) 6. 
power model as directors may "indulge in favouritism" or "shirk on evaluation efforts". ${ }^{120}$ Furthermore, subjective evaluation may encourage concentrating efforts on influencing the evaluator rather than on the actual task. ${ }^{121}$ Consequently, individual targets should be recommended, if at all, as balancing part of a bonus scheme alongside dominant objective standards. ${ }^{122}$

Objective targets reflecting company performance are handled more transparently. Share-pricerelated performance targets are one option. However, as a short-term performance indicator, they are highly susceptible to market abnormalities and purposeful information management by the company. ${ }^{123}$ More common are accounting-based indicators. ${ }^{124}$ There is a vast variety of figures reflecting company earnings or, rather, return on investment in its wider sense. ${ }^{125}$ Neither here nor in any body of corporate governance rules is the place to decide on the adequate measure for each individual case. But companies should show awareness that even accounting-based targets open up possibilities of manipulation or flexible use of rules to enhance the eligibility under bonus schemes. Earning-related compensation can also be boosted by omitting investments in intangible assets such as research and development. ${ }^{126}$ The manipulation of earnings seems to be a common practice. ${ }^{127}$

As a result, Healy strongly advocates a bonus bank system, ${ }^{128}$ which is based on annual bonuses but effectively awards long-term performance. Only a certain percentage of the (accumulated) annual bonuses is paid out every year. Furthermore, the annual bonus can have a negative value due to underperformance which is then charged against the amount accumulated in the bank. This way

120 Oyer, above n 119, 7. See also Kevin J Murphy "Performance Measurement and Appraisal: Motivating Managers to Identify and Reward Performance" in William J Bruns (ed) Performance Measurement, Evaluation, and Incentives" (Harvard Business School Press, Boston, 1992) 57.

121 Oyer, above n 119,7

122 Compare Oyer, above n 119, 7. It should be noted that the SCNZ Guidelines, above n 68, Principle 5.4 expressly mention both target types.

123 Jennifer Hill and Charles M Yablon "Corporate Governance and Executive Remuneration: Rediscovering Managerial Positional Conflict" (2002) 25 U NSW LJ 294, 308; Sheppard, above n 35, para 8.

124 For Australia see ACSI CEO Pay, above n 106, para 4.1.2.

125 Sheppard, above $\mathrm{n} 35$, para 7 provides an overview.

126 P M Dechow and R G Sloan "Executive Incentives and the Horizon Problem: An Empirical Investigation" (1991) 14 JAE 51, 54.

127 See Sheppard, above n 35, para 7 and 9. For the United States see Keith J Crocker and Joel Slemrod The Economics of Earnings Manipulation and Managerial Compensation (Seminar Paper, University of Pennsylvania, 2005). See also Crystal, above n 21, 85 .

128 Healy, above n 13, 179. 
companies can hold back short-term incentives until it is proven over time that the reported incidences are evidence of sustainable development. ${ }^{129}$ The implementation of STIPs that do not award cash, but rather so-called deferred shares that must be held for a specified number of years, runs along the same lines. ${ }^{130}$ Instead of charging underperformance against the bonus, ownerinterests are increased through holding shares. ${ }^{131}$ In the end, it is only long-term performance schemes that encourage long-term oriented business strategies.

\section{LTIPs and equity-based instruments}

The keynote of the preceding section was discouraging STIPs, or advocating their integration with a bonus bank system, and thus effectively building a LTIP. More commonly, LTIPs use equitybased instruments (traditionally share-options). These provide executives with the right to buy shares in their employer company over a future period at either a fixed exercise price or at an exercise price increased in a predefined manner. ${ }^{132}$ They usually vest after a certain period of time and, possibly, subject to further specific requirements. ${ }^{133}$ In Australia, there are now a growing number of companies that employ so called zero-exercise-price options (ZEPOs). ${ }^{134}$

Soft law offers a more comprehensive treatment of LTIP-related issues than hard law. After some general remarks, the ASX Principles refer to the IFSA Executive Share and Option Scheme Guidelines for guidance. ${ }^{135}$ These Guidelines are relatively comprehensive. Unfortunately, the reference in the ASX Principles does not give them the character of ASX Principles and thus they need not be reported against. The ACSI Guidelines contain an extensive coverage of factors to be considered when implementing an option or other share incentive scheme. ${ }^{136}$

129 Sheppard, above n 35, para 9.

130 The practical use of such schemes is marginal in Australia, see ACSI CEO Pay, above n 106, para 4.1.2.

131 Joshua A Kreinberg "Reaching Beyond Performance Compensation in Attempts to Own the Corporate Executive" (1995) 45 Duke LJ 138, 160 identifies share ownership by executives as a much neglected factor.

132 See, for a basic overview of the mode of operation of executive option schemes, Aventine Consulting "Executive Options - Practices and Trends in New Zealand" (2003)<http://www.mcanz.co.nz> (last accessed 16 April 2006).

133 Aventine Consulting, above n 132, 1. Vesting determines if and from when the option can be exercised.

134 This term embraces a variety of scheme types such as performance rights or shares, performance award rights, and deferred shares. ACSI Incentive Components, above n 114, para 4.2.3. For New Zealand see Aventine Consulting, above n 132, 3.

135 IFSA Guidance Note No 12, above n 76.

136 ACSI Guidelines, above n 77, paras 14.5-14.8. 
(a) General value of options and share-based schemes

There is abundant criticism of option and share-based schemes. But if the framework and the details of a scheme are well-designed, the scheme can be an effective tool. Share incentive schemes aim to put the executive in a shareholder-like position. Other performance-related schemes are to a greater extent artificial and not capable of simulating true long-term ownership. ${ }^{137}$ By simulating a long-term ownership position the executive is given incentives to create sustainable value instead of manipulating company data in his or her favour. ${ }^{138}$ The alignment of interests between shareholders and executives through options is, however, sometimes alleged to be weak. ${ }^{139}$ Shareholders face the cost of providing capital and suffer from decreasing share prices in case of underperformance. The executive holding options does not face this particular risk. In the worst case, the options are not worth exercising. ${ }^{140}$ Yet, the risk of the undiversified executive can be considerable if substantial parts of the remuneration are at risk of dropping out. ${ }^{141}$ Thus, the alignment of interests is not necessarily weak; but a sufficient amount at risk is crucial. In this context, codes such as the NZX Best Practice Code could and should demand a substantial portion of pay to be awarded under equity performance schemes. ${ }^{142}$

The long-term view constitutes a LTIP. The NZX Best Practice Code states a vesting period of two years ${ }^{143}$ while other guidelines mostly suggest a three-year minimum period. ${ }^{144}$ While a general decision for any number of years appears rather arbitrary, a two-year period is still in the vicinity of annual STIPs. ${ }^{145}$ In Australia, the practice of phased vesting is developing, whereby several tranches of options vest earlier than after three years. Under the cover of an LTIP this practice does not seem acceptable.

137 Kreinberg, above n 131, 172.

138 Shaun Clyne "Modern Corporate Governance" (2000) 11 AJCL 5, 10; Kreinberg, above n 131, 160.

139 Healy, above n 13, 186.

140 Clyne, above n 138, 10; Villiers, above n 110, 141.

141 See above Part V B Fixed Remuneration.

142 Compare the current version of NZX Best Practice Code, above n 66, para 2.7. The same applies for the ASX Principles. An article has identified a ratio of one-third fixed to two-third performance related remuneration as future best practice standard, see Brooks, above n 112, 370 .

143 NZX Best Practice Code, above n 66, para 2.7.

144 ACSI Guidelines, above n 77, para 14.6. See also the comparison in ACSI Incentive Components, above $\mathrm{n}$ 114, para 4.2.4

145 But see Crystal, above n 21, 184: An appropriate period can be estimated; it will vary from industry to industry but will virtually never be below three years. 
(b) Perceived inexpensiveness of options and share issues

In the past, options were sometimes said to be "a cheap way to remunerate executives ...."146 Yet, options or new shares in general are by no means cheap or gratuitous. ${ }^{147}$ The economic cost of an option or share issue is the opportunity cost - that is the amount the company could raise for an option or share if sold to an outside investor rather than giving it to the executive. Simply because there is no market for issues with characteristics similar to those granted to executives, the opportunity costs are not obvious. ${ }^{148}$ This fact is now widely acknowledged, and costs must increasingly be recognised in companies' earning statements. ${ }^{149}$ New Zealand International Financial Reporting Standards (NZ IFRS) specify that all New Zealand companies must begin to recognise share option grants at their grant date "fair value" by no later than $2007 .{ }^{150}$ In Australia, the same already applies. ${ }^{151}$ The "fair value" is essentially the one attributed to the options if traded on the marketplace. ${ }^{152}$ As a consequence, the accounting inconsistencies that were regarded as a downside of equity incentive schemes will soon belong to the past.

(c) The problem of dilution

A problem with any LTIP that operates on the basis of the issue of new shares is the scheme's dilutionary impact on the existing shareholders' positions in terms of share value, dividends and voting power. ${ }^{153}$ In New Zealand, the dilution aspect is addressed by shareholder approval. No right is to be abridged without the consent of the shareholders affected. ${ }^{154}$ This inclusion of shareholders appears to be an acceptable design. ${ }^{155}$ Share appreciation rights and phantom shares avoid dilution

146 Clyne, above n 138, 13.

147 "Explaining Executive Compensation", above n 96, 858; Healy, above n 13, 186.

148 "Explaining Executive Compensation", above n 96, 867.

149 Helen Roberts, Glenn Boyle and Stefan Clyne "How Much Do Employee Stock Options Really Cost?" (Seminar Paper, University of Otago, 6 May 2005) 1.

150 New Zealand Institute of Chartered Accountants NZ IFRS 2 Share-based Payment (November 2004) $<$ http://www.nzica.com> (last accessed 16 April 2006)

151 Australian Accounting Standards Board (January 2005) Standard 2 Share-based Payment.

152 Usually calculated on the basis of the Black-Scholes Formula: see Roberts, above n 149, 1.

153 Angela G Morgan and Annette B Poulsen "Linking Pay to Performance - Compensation Proposals in the S\&P 500" (2001) 62 JFE 489, 498; IFSA Guidance Note No 12, above n 76, para 8.1.

154 NZX Listing Rules, above n 39, r 7.3.1(a). Note that the exceptions in rules 7.3.5 and 7.3.6 do not apply to directors; yet rule 7.3.6 allows general employee share issues on a small scale.

155 See Part VI B 2 Shareholder power and activism. 
completely as they are based on fictional shares only; cash rewards obtained under such schemes should at least be partly required to be invested in existing company shares. ${ }^{156}$

(d) Avoiding windfalls: challenging performance targets?

A major problem with share options, and likewise with other instruments based on the increase of share prices, is windfall gains, ${ }^{157}$ which arise if a company's share price increases due to general market movements. ${ }^{158}$ A study conducted for the United States reports that while 30 per cent of the share price movement reflects corporate performance, the remaining 70 per cent are the product of general market conditions. ${ }^{159}$ Particularly problematic are plain vanilla options. Exercising these is not dependent on any further performance indicator. They appear to qualify without restriction as equity-based LTIPs under the NZX Best Practice Code. ${ }^{160}$ Thus, a company can issue a feel-good statement of compliance, while its executives can benefit from general market trends. ${ }^{161}$ The ASX Principles are fairly vague. But a scheme of the described nature features no "clear relationship between ... performance and remuneration."162 The Australian Corporations Act 2001 is clear. Companies that choose to issue securities as remuneration not dependent on performance hurdles must justify this choice. ${ }^{163}$ This indicates a clear preference without making overly detailed prescriptions. The IFSA Principles and also the ACSI Guidelines go one step further. They make positive statements that share schemes must feature challenging performance hurdles. ${ }^{164}$ Clear preference is given to relative performance hurdles. The IFSA Guidelines require the company's performance at least not decline relative to its peer companies. ${ }^{165}$ The ACSI Guidelines even require the company to be ahead of at least half of its peer companies' performance or preferably that vesting is made dependent on a sliding scale of performance relative to peer companies. ${ }^{166}$ It is

156 Brooks, above n 112, 372; Crystal, above n 21, 160.

157 Pay Without Performance, above n 13, 138.

158 Villiers, above n 110, 142; David Knott "Corporate Governance - Principles, Promotion and Practice" (Inaugural Lecture - Monash Governance Research Unit, Melbourne, 16 July 2002) 10.

159 Pay Without Performance, above n 13, 139. See also Marianne Bertrand and Sendhil Mullainathan "Are CEOs Rewarded for Luck? The Ones Without Principals Are" [2001] Quarterly Journal of Economics 901, 902.

160 NZX Best Practice Code, above n 66, para 2.7

161 Rather executive directors, as the NZX Best Practice Code only addresses directors.

162 ASX Principles, above n 73, Principle 9.2.

163 Corporations Act 2001 (Cth), s 300A(1)(d)

164 IFSA Guidance Note No 12, above n 76, para 7.4; ACSI Guidelines, above n 77, para 14.5.

165 IFSA Guidance Note No 12, above n 76, para 7.5.

166 ACSI Guidelines, above n 77, para 14.5. 
worth noting that these concepts do not effectively reduce windfalls if the performance target is met. ${ }^{167}$ Linking the option's exercise price to a market or peer group index appears to be a simultaneously convenient and more effective method to address this problem. ${ }^{168}$ However, indexing as such is not addressed in any body of rules.

(e) Exercise price, discounts and re-pricing

The exercise price is an important component of an option scheme. Issuing options on the basis of a discounted exercise price is generally considered bad practice. ${ }^{169}$ In effect, this introduces a fixed base level of gains disguised as performance-related remuneration. ZEPOs are generally not considered. Their very nature is to have no exercise price. As the gain per ZEPO equals the share price of the vesting date and not only the difference between the latter and the exercise price, the gains per option are greater than usual. Consequently, a smaller amount of options needs to be issued, which has favourable effects on dilution. ${ }^{170}$ ZEPOs also eliminate all-or-nothing scenarios of conventional options and thus arguably the incentive to manipulate share prices. ${ }^{171}$ At the same time, ZEPOs still provide awards if the share price decreases over time. This constitutes a questionable concept. The ASIC Guidelines now rightly stress the particular need for additional challenging performance hurdles. ${ }^{172}$

In the United States, the practice of re-pricing "out-of-the-money" options appears to be a problem. ${ }^{173}$ On one side, executives holding out-of-the-money options are said to lose any incentive to perform. On the other side, it is fair to say that the expectation of re-pricing reduces incentives to perform right from the beginning. Indexing was mentioned above as a means to reduce windfalls. If the index works both ways it can also - legitimately - protect executives against negative market movements. Executives are, however, not protected against their own under-performance. ${ }^{174}$ Considering the fact that at least the disguised equivalent of re-pricing, namely issuing new options

167 Pay Without Performance, above n 13, 142.

168 Ferrarini and Moloney, above n 7, 7; Pay Without Performance, above n 13, 140.

169 But see the ACSI Incentive Components, above n 114, para 4.2.3 for admissibility in exceptional circumstances.

170 ACSI Incentive Components, above n 114, para 4.2.3.

171 ACSI Incentive Components, above n 114, para 4.2.3.

172 ACSI Guidelines, above n 77, para 14.5.

173 Lucian Bebchuk, Jesse Fried and David Walker "Managerial Power and Rent Extraction in the Design of Executive Compensation" (2002) 69 U Chi LR 751, 759.

174 Pay Without Performance, above n 13, 166. 
with a lower exercise price, occurs in Australia ${ }^{175}$ and presumably in New Zealand as well, respective statements in corporate governance rules should be considered. ${ }^{176}$ A useful way to address the re-pricing problems, besides indexing, appears to be the reduction of one-time lump sum grants in favour of more frequent grants. ${ }^{177}$

\section{(f) Conclusion for rules regarding LTIPs}

As shown, quite a few fundamental issues need to be taken into account when designing an option or share incentive scheme that effectively links pay to performance rather than just giving chances of undeserved gains. A compilation of important factors for consideration in the design of equity performance schemes, such as the one provided in the ACSI Guidelines, should not be feared to be out of place in stock exchange corporate governance codes or even a statutory disclosure regime. It would rather be a useful tool to force companies to debate the crucial issues and account for how they deal with them.

\section{Termination Payments}

Payments upon loss of office are a major concern in the remuneration debate. ${ }^{178}$ The debate focuses on true termination payments rather than retirement benefits. ${ }^{179}$ One relatively unproblematic case is that of the executive leaving voluntarily, particularly after a successful time in office. Payments for breach of contract by the company are excluded. The only issue is the fate of long-term incentives as future company performance can not be entirely attributed to the relevant executive. The ACSI Guidelines no longer state that options and share issues should become void. ${ }^{180}$ It is a matter of fairness that a good leaver can participate in the long-term performance whose origins lay in his or her term of office. Thus, pro rata exercising should be tolerated if termination occurs between the vesting period and an exercising period of one year after termination. ${ }^{181}$ All this applies only if performance hurdles are met. Generally, the issue of options shortly before a known termination date should be discouraged. ${ }^{182}$

175 ACSI Incentive Components, above n 114, para 4.2.11.

176 ACSI Guidelines, above n 77, para 14.6 address the issue of re-pricing.

177 ACSI Incentive Components, above n 114, para 4.2.2.

178 See Healy, above n 13, 184.

179 Continuous payments into a retirement benefit scheme qualify as fixed remuneration for the present purposes.

180 ACSI Guidelines, above n 77, para 14.8. The Guidelines thus refrain from a "golden handcuffs" approach that supposedly helps to keep key personnel.

181 ACSI Guidelines, above n 77, 14.8; ACSI Incentive Components, above n 117, para 4.2.13.

182 ACSI Incentive Components, above n 114, para 4.2.13. 
Where the company terminates the contract with cause, payments for breach of contract are excluded and incentive entitlements are usually forfeited. ${ }^{183}$ But mere under-performance does not constitute a cause. In this case, the necessary payments are unjustified from the point of view of performance-related remuneration. The ASX Principles appropriately recommend that clear performance expectations are set out right at the beginning of the contract period. ${ }^{184}$ Favourably, the contract would provide for liquidated damages dependent on the degree of under-performance. ${ }^{185}$ As for LTIPs specifically, a well-designed scheme should not authorise large payments in case of underperformance anyway. Furthermore, a good remedy appears to be the shortening of contract periods to one year or even less. ${ }^{186}$ While this adds insecurity to the executive's contract, which in turn may put upward pressure on remuneration demands for the operating time of the contract, ${ }^{187}$ it is suggested here that current remuneration offers better options of linking pay to performance than do compensation payments. ${ }^{188}$

While the issue of retirement benefits is identified in the New Zealand Securities Commission's Guidelines for non-executive directors, the Guidelines remain silent on executives. ${ }^{189}$ This applies even more so to the NZX Best Practice Code. ${ }^{190}$ The New Zealand Companies Act 1993 only includes compensation payments in the general fairness provision. ${ }^{191}$ The problem of termination payments is more specifically addressed in the Australian Corporations Act $2001 .{ }^{192}$ In essence, it requires shareholder approval for termination payments, except for genuine damages for breach of contract to a specified extent. ${ }^{193}$ Thus, overly large termination payments after only very short times of office - as they are at the centre of current public criticism - are no longer a day-to-day board responsibility and factually discouraged. This also applies to extra-contractual appreciation awards

183 ACSI Incentive Components, above n 114, para 4.2.13.

184 ASX Principles, above n 73, Principle 9.2.

185 ACSI Guidelines, above n 77, para 14.1 only recommend an absolute limit of 12 months base salary.

186 Hans C Hirt "Regulation of Directors' Remuneration: the German Approach, the DTI's Consultation Paper and the Way Forward" (2004) 15 ICCLR 154, 159.

187 DTI Rewards for Failure, above n 89, para 3.8.

188 See Hirt, above n 186, 160.

189 SCNZ Guidelines, above n 68, Principle 5.5.

190 NZX Best Practice Code, above n 66, para 2.7.

191 Companies Act 1993, s 161(1). Note that the introduction of exactly such a "fairness control" was declined in Britain, see DTI Rewards for Failure, above n 89, para 3.11.

192 Corporations Act 2001 (Cth), ss 200A-J.

193 Corporations Act 2001 (Cth), s 200F. 
given ex-post. ${ }^{194}$ The ACSI criticism is, however, that the threshold is too high and should lie at a maximum of twelve months' base salary. ${ }^{195}$

Combined, the Australian rules - in contrast to the New Zealand ones - cover most of the relevant points. Yet, the ASX Principles could be more precise in their stipulations. The ACSI Guidelines show that the debate has moved on in some points.

\section{E Conclusion: Substantive Issues of Executive Remuneration}

The regulatory frameworks in New Zealand and Australia pay little attention to the substantive make-up of remuneration agreements. Yet private bodies of rules, particularly the ACSI Guidelines, demonstrate that the various issues can be addressed with a set of principles. ${ }^{196} \mathrm{New}$ Zealand generally follows a minimal intervention policy as advocated by the Securities Commission. ${ }^{197}$ Boards are believed to be best able to sort out the policies fitting their specific circumstances. A "tick-the-box" mentality should be avoided. ${ }^{198}$ In view of the managerial power theory, there are doubts about a board's ability to find the best solutions. Checking remuneration agreements and policies against a set of principles appears helpful and does not necessarily create a tick-the-box mentality. The provisions for termination payments in the Australian Corporations Act 2001 show that hard law can only set minimal substantive standards. ${ }^{199}$ Yet, as seen in the context of share incentives and performance hurdles, hard law disclosure rules can express a preference for certain typical features, a deviation from which requires justification. This preserves business flexibility. Likewise, "comply-or-explain" principles leave the necessary freedom. A comprehensive set of principles as contained in the ACSI Guidelines could be implemented this way. In combination with disclosure requirements and shareholder involvement, which are discussed in the following part, this could be an effective tool to control executive remuneration in the interest of the shareholders. The New Zealand attitude appears overly laissez-faire and unsuitable to address the issue of linking remuneration to performance.

194 The performance relation of these is particularly doubtful.

195 ACSI Guidelines, above n 77, para 14.1.

196 But see also the nearly principle-based discussion paper of the NZSA (Sheppard, above n 35) for New Zealand and the IFSA Guidance Note No 12, above n 76.

197 Jane Diplock "Corporate Governance: Role of the Regulator" (Legal Research Foundation Conference, Auckland, 18 February 2005) 11; Cathy Quinn "Corporate Governance Post-Enron" (Legal Teachers' Forum, Wellington, 8 July 2005) ["Corporate Governance Post-Enron"].

198 "Corporate Governance Post-Enron", above n 197.

199 Compare Yablon, above n 36, 1886. 


\section{PROCEDURAL ISSUES}

While the previous section dealt with the outcome of the determination process, the procedural issues section deals with the process itself. If the process of remunerating can be disencumbered from its deficiencies, ${ }^{200}$ the outcome of the process should ideally move in the desired direction. While judicial control of remuneration decisions is a possibility, the emphasis must lie on innercompany mechanisms. Disclosure of remuneration is of general value.

\section{A Government Intervention}

Remuneration decisions are preferably made within the company context. ${ }^{201}$ State regulatory authorities are no longer seriously considered. ${ }^{202}$ Executive remuneration is too much a business issue to be regulated by a government authority. ${ }^{203}$ The common form of direct, retrospective State intervention is the judicial process. Both in New Zealand and Australia, the starting point for challenging executive remuneration decisions in the courts is the fairness provisions contained in the applicable company law. ${ }^{204}$ If there are no reasonable grounds for the remuneration being fair, a New Zealand company can start proceedings against the recipient director. ${ }^{205}$ The board representing the company will rarely challenge its own decisions, ${ }^{206}$ therefore bringing proceedings is a field of derivative actions. ${ }^{207}$ The same applies to Australian companies. ${ }^{208}$

The obstacles shareholders encounter in a derivative action when challenging remuneration decisions are twofold. First, the barrier to bring an action must be overcome. ${ }^{209}$ Favourably for

200 See Part III B The Conflict of Interest in Setting Remuneration.

201 See for example Hirt, above n 186, 161.

202 But see I M Ramsay "Directors' and Officers' Remuneration: The Role of the Law" [1993] JBL 351, 370; Clyne, above n 138, 17.

203 Ramsay, above n 202, 370 and Clyne, above n 138, 17.

204 See Part V A Regulation of Remuneration Agreements; Companies Act 1993, s 161 and Corporations Act 2001 (Cth), s 211. Note that any contravention of the provision of the Australian Corporations Act 2001 can also be sanctioned criminally; Corporations Act 2001 (Cth), s 1311. This criminalisation is, however, not endorsed by the courts: John H Farrar "Corporate Governance and the Judges" (2003) 15 Bond LR 49, 57.

205 Companies Act 1993, s 161(5). It should be noted again that this provision only affects executive directors but not sole executives. In case of sole executives an action based of breach of fiduciary duty must be considered, which only adds to the complexity of the process: Kreinberg, above n 131, 170.

206 Randall S Thomas and Kenneth J Martin "Litigating Challenges to Executive Pay: An Exercise in Futility?" (2001) 79 Wash U L Q 569, 576.

207 Companies Act 1993, s 164.

208 Clyne, above n 138, 51. See Corporations Act 2001 (Cth), ss 211 and 236.

209 Companies Act 1993, s 164; Corporations Act 2001 (Cth), s 237. 
shareholders, the costs of the litigation may in part or whole be ordered to be borne by the company. ${ }^{210}$ More significant is the second problem that shareholders must establish unfairness although they lack insight into the internal board processes ${ }^{211}$ and the courts are generally reluctant to judge remuneration packages. ${ }^{212}$ The courts' reluctance has been expressed with regard to amounts of remuneration, ${ }^{213}$ but must apply even more to the make-up of a remuneration agreement. ${ }^{214}$ Only if decisions are devoid of any rational basis, which is hard to establish if professional consultants are engaged, will a court consider unreasonableness. ${ }^{215}$ Accordingly, cases of litigation, particularly successful ones, are rare. ${ }^{216}$ The courts' reluctance is ascribed to the courts being confronted with highly specialised contracts while lacking clear benchmarks. ${ }^{217}$ The terminology "reasonable" or "fair" is hardly clear. ${ }^{218}$ Yablon suggests defining the appropriate test as "reasonable in relation to the corporate benefits expected." 219 Such a definition could also include a review of the value and efficiency of performance components.

With increasing disclosure, the task of the courts to find appropriate benchmarks is assisted. ${ }^{220}$ Practices generally established and stipulated in the industry could be a standard. ASIC $v$ Rich is a benchmark decision in this respect. ${ }^{221}$ Rather than to "rely on unassisted armchair reflection" the court resolved the relevant corporate governance issue 222 by reference to "contemporary community expectations" which included the current corporate governance literature and also corporate

210 Companies Act 1993, s 166 and Corporations Act 2001 (Cth), s 242. See MacFarlane v Barlow (1997) 8 NZCLC 261, 470 (HC) and Frykberg $v$ Heaven (2002) 9 NZCLC 262, 996 (HC) for contrasting application of the New Zealand provision.

211 Clyne, above n 138, 52.

212 Michael Quinn "The Unchangeables - Director and Executive Remuneration Disclosure in Australia" (1999) 10 AJCL 2, 3 ["The Unchangeables"].

213 Re Halt Garage (1964) Ltd [1982] 3 All ER 1016, 1023 (Ch) Oliver J.

214 Compare Ramsay, above n 202, 357.

215 Clyne, above n 138, 52; See also Kreinberg, above n 131, 170.

216 Guinness plc v Saunders [1990] 2 AC 663 (HL) does not address the substantive issue of the remuneration paid. The exceptional circumstances of Crichton v Amaru (2001) 9 NZCLC 262, 549 (HC) are hardly representative of remuneration review issues as discussed here.

217 "The Unchangeables", above n 212, 3.

218 See Part V A Regulation of Remuneration Agreements.

219 Yablon, above n 36, 1897.

220 For a thorough discussion of disclosure issues see Part VI C Disclosure.

221 ASIC $v$ Rich [2003] NSWSC 85.

222 The Court had to decide on the scope of the duties of a chairman. 
governance "exhortations and codes".223 The question is therefore whether standards for remuneration practices are reflected in corporate governance codes issued by the stock exchanges or even private institutions. ${ }^{224}$ As seen above, in Australia especially, the latter provide sometimes detailed guidance. The New Zealand no-or-broad-principles approach is of no help and should be reconsidered for this reason alone.

\section{B Internal Mechanisms of Control}

Besides external and retrospective control, the process of setting remuneration within the company itself deserves attention. The classic way to address the potential conflict of interest in the process is the establishment of remuneration committees (RCs). The notion of allowing enhanced shareholder involvement in the actual process of determination is relatively new.

\section{Remuneration committees}

RCs were the first answer given to the problem of the conflicts of interest within the board 225 and are designed to objectify the pay setting process. ${ }^{226}$ First, the RC should be an independent committee. That means on the one hand that the committee is a body solely focussed on remuneration issues. ${ }^{27}$ This enables the company to bundle existing board expertise and also RC members to concentrate on gaining further expertise. On the other hand, it means that the RC should be independent in the sense of being free from the influence of those whose remuneration is determined. ${ }^{228}$ This includes, for example, the chief executive not being on the RC and the RC being able to independently appoint external consultants for expert advice. ${ }^{229}$ Second, the committee should consist of so-called independent non-executive directors. While boards consisting of exclusively independent members may not be ideal, ${ }^{230}$ a high degree of independence seems essential for RCs in order to minimise influence from the executive side. ${ }^{231}$

223 ASIC v Rich, above n 221, para 70 Austin J.

224 For the ASX Listing Rules see "Comply or Comply", above n 62, 213.

225 See for example the Greenbury Report, above n 27, para 2 which already lists many of the basic features of a well-structured RC that will be discussed below. In the United States RCs have been common practice since even earlier.

226 Greenbury Report, above n 27, para 4; Ferrarini and Moloney, above n 7, 9.

227 If not further labelled, the "committee" refers to the "remuneration committee".

228 Remuneration: Where We've Been, above n 99, 51.

229 Remuneration: Where We've Been, above n 99, 51.

230 Core, above n 18, 34 .

231 Ferrarini and Moloney, above n 7, 9. 
In fact, the use of RCs is wide-spread in practice and also embraced by the relevant bodies of rules in New Zealand and Australia. ${ }^{232}$ While hard law does not address the topic, both countries' stock exchange codes encourage the use of RCs. ${ }^{233}$ They do not, however, go as far as literature suggests they should. ${ }^{234}$ The NZX Best Practice Code does not require members to be nonexecutive or even independent and the ASX Principles require only a majority. Both would allow the chief executive director to sit on the committee. ${ }^{235}$ Independent powers are stressed in neither code. $^{236}$ Therefore, what is labelled best practice in New Zealand and Australia is not ideal when measured against standards advocated in literature or even practised in other countries. This adds to problems that exist with RCs in general. Even independent directors, who in essence do not have too close ties to the company personally or economically, ${ }^{237}$ are directors. Thus many of the arguments supporting the existence of conflicts of interest in favour of executives still have value. ${ }^{238}$ Some studies even suggest that there is no specific relation between increased board independence and improved remuneration policies. ${ }^{239} \mathrm{~A}$ further issue is that substantial shareholders do not qualify as independent. ${ }^{240}$ The ASX Principles leave room for shareholder representation, as not all directors need to be independent. They do not, however, recommend that any shareholder representatives or directors closely associated with shareholders should be on the RC. In contrast to that, Dorff suggests that the only way to counter the executive-friendly altruism of directors is to introduce elements that are by nature more inclined to be altruistic towards shareholders. He wraps this suggestion tentatively in the form of a "random shareholder committee" that works alongside the RC

232 Australian Council of Superannuation Investors Board Composition and Non-Executive Director Pay in the Top 100 Companies: 2003 (2004) <http://www.acsi.org.au> (last accessed 16 April 2006) para 4.1.

233 NZX Best Practice Code, above n 66, para 3.7 and ASX Principles, above n 73, Principle 9.2. But note that the wording of the former suggests that the RC's competence only encompasses remuneration "as director".

234 Note that even the ACSI Guidelines, above $\mathrm{n}$ 77, which have proved to be very comprehensive on substantive matters, do not surpass the detail of other codes in this context.

235 At least the chair should be independent under the ASX Principles.

236 The Combined Code 2003, which is part of the Financial Services Authority Listing Rules in England, demonstrates that raised standards work in practice: Financial Services Authority $<$ http://www.fsa.gov.uk $>$ (last accessed 16 April 2006).

237 The ASX Principles, above n 73, Principle 9.1, contains a good descriptive definition, in contrast to the NZX Listing Rules, above n 39, which do not contain one at all.

238 See Part III B The Conflict of Interest in Setting Remuneration; Ferrarini and Moloney, above n 7, 9.

239 Sanjai Bhagat and Bernard Black "The Uncertain Relationship between Board Composition and Firm Performance" (1999) 54 Business Lawyer 921, 931.

240 ASX Principles, above n 73, Principle 9.1. Substantial means effectively holding more than 5 per cent of the shares, Corporations Act 2001 (Cth), s 9. 
and represents the shareholder perspective. ${ }^{241}$ Effectively, any shareholder affiliation of directors would help. This could also be reached by increased share ownership by directors, ${ }^{242}$ as considered by the NZX Best Practice Code. ${ }^{243}$ All in all, RCs are a welcome step to objectify the remunerating process. But even if the best practice advocated both in New Zealand and Australia is sharpened towards more authority, independence and shareholder representation, RCs alone do not suffice. ${ }^{244}$

\section{Shareholder power and activism}

Shareholder involvement is fundamental to addressing the conflict of interest that a board, even a RC, experiences. Besides derivative actions and shareholder representation on RCs, enhanced direct shareholder involvement deserves a closer look.

(a) Should shareholders have a say?

Direct involvement of shareholders is rejected by proponents of director primacy: "[p]ublic corporations are not participatory democracies ... . ${ }^{245}$ The divergent interests of a dispersed group of shareholders make consensus-based decisions impractical if not impossible. ${ }^{246}$ Thus, business decisions, including remuneration policies and agreements, are reserved for the board. ${ }^{247}$ This view, however, is based on existing and not so much on desirable legal structures. It focuses on the existing separation of ownership and control rather than asking whether this separation should be bridged. ${ }^{248}$ Bebchuk endorses increased shareholder decision power for fundamental "Rules-of-theGame Decisions", ${ }^{249}$ which include executive remuneration. ${ }^{250}$ Business decisions generally cannot

241 "Altruistic Theory", above n 51, 878.

242 Ferrarini and Moloney, above n 7, 9.

243 NZX Best Practice Code, above n 66, para 2.7. See for Australia ACSI Guidelines, above n 77, para 14.11.

244 David Ablen "Remunerating 'Fairly and Responsibly': The 'Principles of Good Corporate Governance and Best Practice Recommendations' of the ASX Corporate Governance Council" (2003) 25 Sydney L Rev 555, 559.

245 Steven M Bainbridge "Director Primacy: The Means and Ends of Corporate Governance" (Research Paper, Los Angeles School of Law, 2002) 10 ["Director Primacy"].

246 "Director Primacy", above n 245, 13.

247 "What Reward Have Ye?", above n 28, 234; Andrew Griffiths "Directors' Remuneration: Constraining the Power of the Board" [1995] LMCLQ 372, 373.

248 James McConvill and Mirko Bagaric "Towards Mandatory Shareholder Committees in Australian Companies" (2004) 28 Melb U LR 125, 136.

249 Lucian Bebchuk "The Case for Increasing Shareholder Power" (2005) 118 Harv L Rev 833 ["Shareholder Power"]. Note that in the United States shareholders enjoy considerably less rights than in jurisdictions influenced by English law.

250 If shareholders choose to make these decisions: "Shareholder Power", above n 249, 892. 
be subject to shareholder resolutions; but against the background of the importance of executive remuneration as an incentive in the agency conflict, remuneration can virtually set the rules of the game. $^{251}$

Although it is therefore desirable to give shareholders a say on executive remuneration, there still exist problems with shareholder decisions. Shareholders may be uninformed and lack the necessary expertise. ${ }^{252}$ They may be (rationally) apathetic or disinterested ${ }^{253}$ and encounter collective action problems. ${ }^{254}$ But an appropriate legal framework can overcome most of these problems. Shareholder activism is to some extent possible without specific regulation. Larger institutional investors are regularly cited as factors of influence. ${ }^{255}$ However, they also face collective action problems as their individual holdings are usually small for reasons of diversification. ${ }^{256}$ It might also be desirable to include as many diverse shareholders as possible in the process of influence and not only one group. ${ }^{257}$ Thus, the framework for participation must be examined.

(b) Shareholder committees

The idea of random shareholder committees (SCs) was mentioned in the context of RCs. SCs are to some extent common practice in the United States but neither prescribed nor common practice in Australia or New Zealand. ${ }^{258}$ SCs reduce collective action problems and the costs of voicing shareholder views. ${ }^{259}$ But their effect may not surpass the mere "formaliz[ation of] existing

251 Kreinberg, above n 131, 178, does not regard remuneration as common business decision.

252 Griffiths, above 247, 373; "Director Primacy", above n 245, 15.

253 "Director Primacy", above n 249, 15.

254 Ferrarini and Moloney, above n 7, 10.

255 "Agents With and Without Principals", above n 111, 206; Hemraj, above n 111, 346; Introduction to Company Law, above n 8, 141.

256 Klaus J Hopt Modern Company and Capital Market Problems - Improving European Corporate Governance after Enron (ECGI Working Paper, Hamburg, November 2002) 5; Introduction to Company Law, above n 8, 143.

257 Ferrarini and Moloney, above n 7, 10 notes that institutional investors might be prone to following personal short-term goals. Introduction to Company Law, above n 8, 143 describes situations of conflicts of interest involving institutional investors.

258 For Australia see McConvill, above n 248, 129.

259 Edward B Rock "The Logic and (Uncertain) Significance of Institutional Shareholder Activism" (1991) 79 Geo L J 445, 495; McConvill, above n 248, 137. 
management-shareholder exchanges." 260 As committees with limited representation, SCs do not enhance the transparency of proceedings towards shareholders in general. The selection of SC members constitutes a problem. Proponents of SCs suggest a random selection process to ensure representation of the whole spectrum of shareholder interests. ${ }^{261}$ However, it is probable only larger or institutional shareholders would be willing to assume responsibilities in a SC. In the end, the question is whether the existing agency conflicts can be moderated by introducing a third representative body and thus a third agency relationship. ${ }^{262}$ The shareholder voting approach described next appears to be favourable to SCs.

(c) Shareholder voting

Statute-prescribed shareholder votes overcome many of the problems specified earlier. ${ }^{263}$ Mandatory voting eliminates the barrier of the initial impulse. The technical work is still done by the $\mathrm{RC}$ and, if required, by professional advisors. The publication of policy and agreement details that is necessary for a vote reduces rational apathy due to costs of obtaining information. Shareholders may still make uninformed decisions due to insufficient expertise. ${ }^{264}$ However, irregularities and unacceptable practices are likely to be discovered in the process of the submissions for the vote. General disclosure can help to establish benchmarks. Finally, a vote can involve all shareholders while the costs to the individual are limited. ${ }^{265}$

The United Kingdom and recently Australia have established advisory shareholder votes. ${ }^{266}$ Critics call these hybrids with uncertain legal effect. ${ }^{267}$ Yet, their strength derives not from legal

260 Ronald J Gilson and Reinier Kraakman "Reinventing the Outside Director: An Agenda for Institutional Investors" (1991) 43 Stan L Rev 863, 872.

261 This leads to a rather complicated selection process design, McConvill, above n 248, 148.

262 Gilson, above n 260, 872 speaks of a "shadow board" that suffers from the same shortcomings as the traditional board.

263 The may be prescribed in any other way.

264 Interestingly, this view was shared by the Australian Shareholders' Association: Joint Committee on Corporations and Financial Services "CLERP (Audit Reform and Corporate Disclosure) Bill 2003" (Official Committee Hansard, 9 March 2004) 28 [CLERP 9 Hansard], while Clyne, above n 138, 20 attributes the responsibility of informing shareholders to the Australian Shareholders' Association.

265 Lee Roach "The Directors' Remuneration Report Regulations 2002 and the Disclosure of Executive Remuneration" (2004) 25 Comp Law 141, 144 notes that the costs of holding an AGM can well surpass the quantity of remuneration granted to a chief executive.

266 Corporations Act 2001 (Cth), ss 250R(2) and (3).

267 See the quote in Hopt, above n 256, 12. 
force but from the market on which they are voiced. ${ }^{268}$ Evidence shows that board decision-making is influenced by the prospect of an advisory vote and boards shy at contradicting a refused advisory approval. ${ }^{269}$ Binding votes can create problems with contractual entitlements negotiated beforehand if they are not approved of later. ${ }^{270}$ Internationally, qualified executives might shun jurisdictions subjecting them to uncertainties of provisional contracts. But certain remuneration components based on share issues are already subjected to binding shareholder approval in many modern jurisdictions without insurmountable practical difficulties. Australian law currently demands a binding vote for termination payments and retirement benefits that surpass certain amounts, as well as unreasonable remuneration. It remains to be seen if such measures are sensible and effective. Generally, advisory votes might be sufficient. ${ }^{271}$

Votes can either concern remuneration policy prospectively or remuneration reports retrospectively. ${ }^{272} \mathrm{~A}$ vote on policy only accommodates privacy concerns. ${ }^{273}$ It is, however, important for shareholders to express views on how a policy is applied in practice. Therefore, it appears reasonable to vote on a retrospective remuneration report which includes both policy and its past application. $^{274}$

The new Australian advisory vote is a welcome step in the direction of more shareholder involvement. Significantly, the remuneration report and therefore the vote not only concern directors' but also executives' remuneration. ${ }^{275}$ This avoids problems with highly-ranked and highlypaid executives who, although not occupying a directorial office, still have considerable influence. In contrast to that, New Zealand shareholders are, if at all, only accidentally involved in the remuneration process. LTIPs that build on the issue of shares, including share options, are subject to

268 It might be considered as an indicator of unreasonableness for the purposes of judicial review, though: Mark Standen and Chris Brown "CLERP 9 and the ASX Corporate Governance Council's Recommendations" (2004) 56 Keeping Good Companies 272, 278.

269 Ferrarini and Moloney, above n 7, 11

270 DTI Rewards for Failure, above n 89, para 3.15.

271 While not entirely clear before, the new ACSI Guidelines approve of the non-binding vote without further demands, ACSI Guidelines, above n 77, para 14

272 See the discussion in the (English) Department of Trade and Industry Directors' Remuneration (Consultative Document, London, December 2001) para 2.24 [DTI Directors' Remuneration].

273 This was considered positive by the English Department of Trade and Industry: DTI Directors' Remuneration, above n 272, para 2.24.

274 DTI Directors' Remuneration, above n 272, para 2.24

275 Compare the English regulations that only address directors' remuneration: DTI Rewards for Failure, above n 89, para 2.2. 
binding shareholder approval under both the Companies Act 1993 and the NZX Listing Rules. ${ }^{276}$ The Listing Rules also require the "precise terms and conditions of the specific proposal to issue" to be subject to the resolution. ${ }^{277}$ These provisions do not, however, aim at controlling executive remuneration but at protecting the rights attached to existing shares from dilution. ${ }^{278}$ While the vote on option and share reward schemes covers important remuneration components, which are particularly susceptible to mis-design, this is not sufficient. Shareholders who are to approve of a share-based LTIP do not know the context in terms of the overall remuneration policy and other components of individual agreements. Furthermore, such a vote does prevent other components from being changed in following years. ${ }^{279}$ However, single components can only be judged in their interrelationship. The use of share-based rewards is low in New Zealand anyway and other major components still evade shareholder scrutiny. Therefore, a vote on a remuneration report should be introduced.

\section{Disclosure}

An adequate disclosure regime is essential to controlling the conflict in the remuneration setting process. Both New Zealand and Australia have a disclosure regime with regard to remuneration in place. The Australian system is, again, very sophisticated. Disclosure rules are found in the Corporations Act 2001 which requires a directors' report to be prepared. ${ }^{280}$ This report $^{281}$ must contain the discussion of the board policy regarding directors' and senior executives' remuneration with particular regard to the relation of remuneration and performance. ${ }^{282}$ It must further disclose the details of individual remuneration packages for each director and the five highest-paid executives in the company. ${ }^{283}$ This requires a detailed description of performance components, including performance hurdles and all information necessary to assess whether these have been met. $^{284}$ Parallel to the Corporations Act 2001 the new AASB Standard 124 requires detailed

276 Companies Act 1993, ss 117(1), 117(2)(b) and 45; NZX Listing Rules, above n 39, r 7.3.1.

277 NZX Listing Rules, above n 39, r 7.3.1.

278 Brookers - Company and Securities Law, above n 38, para CA45.01

279 Mark J Loewenstein "Reflections on Executive Compensation and a Modest Proposal for (Further) Reform" (1996) 50 SMU L Rev 201, 221.

280 Corporations Act 2001 (Cth), s 298. Detailed disclosure is also the central theme of the ASX Principles: ASX Principles, above n 74, Principle 9.1.

281 This is the same report that forms the basis for the advisory vote.

282 Corporations Act 2001 (Cth), s 300A(1)(a).

283 And, if applicable, in the group: Corporations Act 2001, s 300A(1)(c).

284 Corporations Act 2001 (Cth), s $300 \mathrm{~A}(1)(\mathrm{e})$. Note that the provision is so detailed that it is far more sophisticated than the ASIC Guidelines. 
remuneration disclosure for "Key Management Personnel". ${ }^{285}$ Unfortunately, the terminology is not consistent. ${ }^{286}$ A positive feature is that disclosure under accounting rules is part of the financial statement and thus audited. ${ }^{287}$

The New Zealand disclosure rules are very basic. The Companies Act 1993 requires band disclosure for employee remuneration above $\$ 100,000 .{ }^{288}$ Directors' remuneration ${ }^{289}$ is disclosed as a total amount figure for each individual. ${ }^{290}$ For directors, there should also be entries in the interests register which must be disclosed in the annual report of the year in which they are made. ${ }^{291}$ The required content of these entries is not further specified. ${ }^{292}$

In view of the very dissimilar standards of disclosure in New Zealand and Australia the purpose of disclosure of executive remuneration should be examined more closely. With specific regard to remuneration, rationales of disclosure include enabling shareholders to evaluate the performance of management, to understand the costs associated with the agency relationship and to take control of these costs. ${ }^{293}$ Disclosure can also encourage executives to reduce agency costs. ${ }^{294}$ Disclosure of remuneration information is, as a key indicator of corporate governance practices, valuable for the market as such. ${ }^{295}$ It strengthens all market forces aligning interests in the general agency conflict

285 Australian Accounting Standards Board (31 December 2005) Standard 124.

286 As a consequence, different reports may have to be prepared. Compare the definition of Key Management Personnel in Australian Accounting Standards Board (31 December 2005) Standard 124, para 9.

287 Ablen, above n 244, 564; Anne Ward and Gillian Suss "Serving Two Masters: Some Practical Issues Relating to Enhanced Remuneration Reporting" (2005) 57 Keeping Good Companies 94, 96 (Both regarding the former Australian Accounting Standards Board Standard 1024 which was recently replaced by Standard 124)

288 Companies Act 1993, s 211(1)(g).

289 Presumably also in the capacity of executive.

290 Companies Act 1993, s 211(1)(f).

291 Companies Act 1993, ss 161(2) and 211(1)(e).

292 Brookers - Company and Securities Law, above n 38, para CA161.04

293 Clyne, above n 138, 28

294 Clyne, above n 138, 28. Note that the study by Andjelkovic, above n 104, is reluctant to attribute a weak link of remuneration with performance exclusively to missing disclosure.

295 Mark Blair and I M Ramsay "Mandatory Corporate Disclosure Rules and Securities Regulation" in Gordon Walker (ed) Securities Regulation in Australia and New Zealand (2 ed, LBC Information Services, North Ryde (NSW), 1998) 63; Albie Brooks "Australia: Commentary on New Remuneration Disclosure Rules" (2001) 22 Comp Law 60; "What Reward Have Ye?", above n 28, 238. 
discussed at the beginning. ${ }^{296}$ Disclosure also helps to explain executive remuneration to other stakeholders, particularly in the context of pay disparities among company employees. ${ }^{297}$ Disclosure thus does more than "satisfy the prurient curiosity of certain sections of the business community and the investing public ... ${ }^{298}$ Privacy arguments are outweighed by the need for control. ${ }^{299}$ The disclosure of confidential business information can be prevented by means of exceptions; performance targets using such information are relatively rare anyway. ${ }^{300}$ In view of the benefits, the costs of disclosure are marginal. In the process of properly designing remuneration policies and agreements, all the information needed for disclosures must be compiled anyway, so that the costs of disclosure are those of publication only.

Inadequate disclosure can feed envy ${ }^{301}$ and can also serve to camouflage remuneration. ${ }^{302}$ Disclosing mere lump sum amounts, as done in New Zealand for executives and directors, is insufficient. ${ }^{303}$ Those legitimately interested do not learn how these amounts are distributed to the various components and how they relate to company performance. ${ }^{304}$ Such a regime was in place in Australia a decade ago and justly criticised. ${ }^{305}$ The current Australian disclosure regime provides very detailed information. The interested individual is informed about the board policy and how it is applied in practice. Individual performance components and targets can be assessed with regard to company performance and comparable companies. Disclosure does "not mean swamping

296 See Part II A Agency Theory, Managerial Power and Remuneration; "What Reward Have Ye?", above n 28, 238; Ramsay, above n 202, 371

297 See Part II B Excessive Remuneration.

298 Submission in the Australian legislative process, as cited by Clyne, above n 138, 30, and Healy, above n 13 , 180 .

299 Note that information about the income of other groups in society is also publicly available: "What Reward Have Ye?", above n 28, 239.

300 For example ASX Listing Rules, above n 44, r 3.1A.3. But see the problems with the overly wide application of such exceptions under the Sarbanes-Oxley-Act, Martin D Mobley "Compensation Committee Reports Post-Sarbanes-Oxley: Unimproved Disclosure of Executive Compensation Policies and Practices" [2005] Colum Bus L Rev 111, 130.

301 "CEO Incentives", above n 30, 144.

302 "Stealth Compensation", above n 58, 299.

303 See Healy, above n 13, 180, for a graphic comparison of disclosure requirements in New Zealand and Australia. In defence of the New Zealand system it must be stressed that at least the interest register provides some additional information for executive directors.

304 Clyne, above n 138, 30 .

305 "What Reward Have Ye?", above n 28, 239. 
shareholders with a mass of details ... "306 But a remuneration report must be as detailed and complex as is necessary to correctly assess the value of a remuneration package. ${ }^{307}$ Nothing is won by a brief but superficial report omitting important data. The data must be displayed in a manner that makes it easy to inspect. ${ }^{308}$ Standardisation is an important step. ${ }^{309}$ While both the Australian Corporations Act 2001 and the relevant accounting standard deliver a good degree of such standard points, ${ }^{310}$ it is regrettable that they do not form a consistent system. ${ }^{311}$ Tabular standardised disclosure is prescribed by neither, which may impair the suitability for cross-company comparisons. ${ }^{312}$ In New Zealand, if one reverts to the interests disclosure for detailed information about directors' remuneration, this information suffers from missing standardisation, arduous comparability and the fact that information is scattered over various years. Thus, New Zealand law does not guarantee effective disclosure even for directors. ${ }^{313}$

While, in most areas, the Australian disclosure regime meets the high standards set for disclosure regimes, the New Zealand regime cannot be so approved. It is ineffective as a result of not disclosing enough meaningful information and not disclosing it in a standardised form. As disclosure is essential for any form of control over the remunerating process, reform is suggested for the present system. Enhanced disclosure could also reveal to what extent a problem with executive remuneration exists.

\section{Concluding Remarks for Procedural Issues}

The last part has shown that Australia has made some significant steps to safeguard shareholder interests in the remunerating process. Disclosure and shareholder votes are most important but retrospective judicial control may also become more efficient. The New Zealand system shows major deficiencies. Endeavours for reform could take Australia as a role model.

306 Greenbury Report, above n 27, para 5.3; Roach, above n 265, 145

307 Compare Blair, above 295, 68.

308 Ferrarini and Moloney, above n 7, 12

309 "What Reward Have Ye?", above n 28, 244. ACSI CEO Pay, above n 106, para 4.2, indicates that increased standardisation would be helpful for the average investor but as it appears even the professional analyst suffers from the flexibility that used to be before the CLERP 9 reform.

310 Note that while the ASX Principles, above n 73, Principle 9.1, demand disclosure they do not provide any standard and have been criticised for that: Ablen, above n 244, 562.

311 Stephen Walmsley and Grant Dixon "New Regime for Disclosure of Director and Executive Remuneration" (2004) 56 Keeping Good Companies 189.

312 Ablen, above n 244, 562.

313 Note again that sole executives' remuneration is subject to only lump sum disclosure. 


\section{CONCLUSION}

The purpose of this article was to assess the New Zealand and Australian rules regarding the remuneration of company executives. Performance-related remuneration is essential to aligning the interests of company executives with those of shareholders. The traditional process of determining remuneration packages for executives is impaired by agency conflicts. Thus remuneration rules must take into consideration both the substance of remuneration arrangements and the procedure of reaching them. Only a few rules exist for the substantive issues. Soft-law codes show that they are capable of being addressed in a body of rules such as the ACSI Guidelines. Maintaining business flexibility prohibits incorporating such rules in hard law; yet "comply or explain" disclosure regimes are an option. Australia has so far successfully focussed on developing adequate procedural rules. New Zealand has not taken this step yet. Having a closer look at Australia might prove to be helpful. 
(2006) 37 VUWLR 